\title{
LAND USE CHANGING PATTERN AND CHALLENGES FOR AGRICULTURAL LAND: A STUDY ON RAJSHAHI DISTRICT
}

\author{
Md. Rahedul Islam ${ }^{1^{*}}$ and Md. Zahidul Hassan \\ Department of Geography and Environmental Studies, University of Rajshahi, Rajshai 6205, Bangladesh; \\ ${ }^{1}$ Present address: Department of Geography, Environment and Urban Planning, Pabna Science and \\ Technology University, Pabna 6600 \\ *Corresponding author (email: rahe_ges76@yahoo.com)
}

\begin{abstract}
Due to alterations in physiographic and social-economic conditions, climatic changes, adaptation and population growth, the land use pattern of Bangladesh is changing very rapidly. Bangladesh is a small country but it bears a huge population, resulting in a very high density of population and very high intensity of land and resource use. Per capita land is estimated to be only about 0.0526 ha. Two significantly prominent phenomena driving country's overall scenario of economic development and environment imbalance include: (a) the high growth rate of population engulfing precious land for settlement and (b) scarcity of land for ever increasing demand of food. As a result, the land use pattern of the country is changing at a great momentum. Every year the country is losing $1 \%$ arable land due to the population growth and its infrastructure development. This study was conducted on Rajshahi District where the major focus was to see the land use pattern of the area, trend in the change of land uses, and in particular, challenges for the agricultural land. For analyses remotely sensed data (Landsat MSS-1977, TM-1990 and TM2010) and GIS techniques were used and secondary data were collected from SPARRSO, published and unpublished data regarding crop, population and other ambient information from mostly government sources. Results show that the land use pattern of Rajshahi District is changing, especially the agricultural land is decreasing in an alarming rate and now it is become more and more vulnerable. The agricultural land of the study area is losing $0.46 \%$ per year and the area under infrastructure use is increasing $5.86 \%$ per year. If this rate continues, the agricultural land will be totally eliminated within the next 217 years.
\end{abstract}

Key words: Land use, changing pattern, agricultural land, Rajshahi.

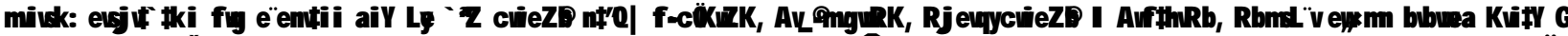

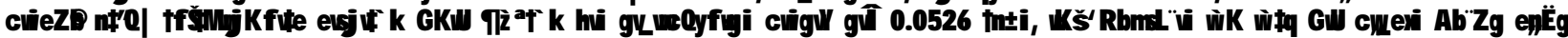
$R b N b \neq Z i \neq f^{\prime} k \mid R b m s L$ "venK I A _

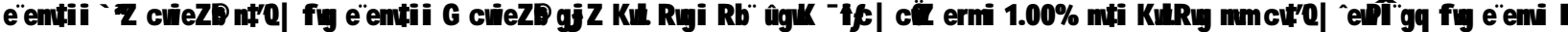

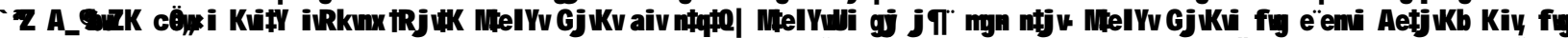

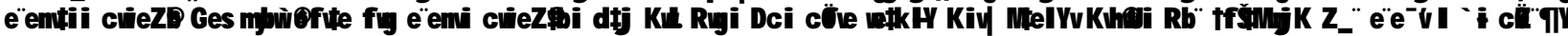

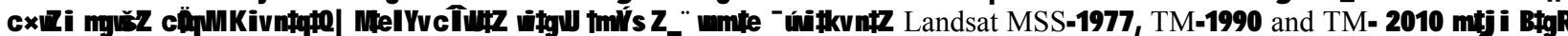

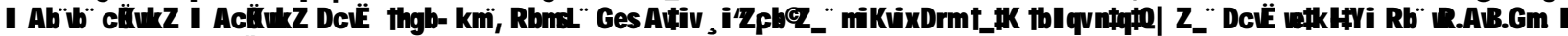

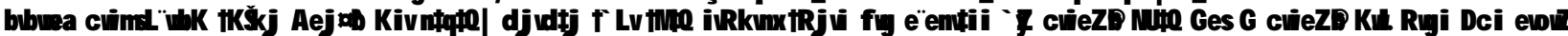

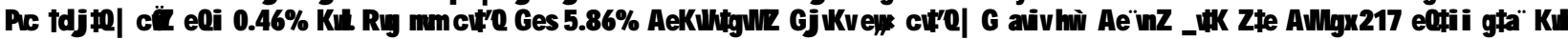

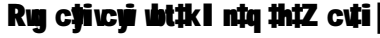

\section{Introduction}

Land use pattern of a country reflects its socio-economic stipulation. While land use changes are concerning topics in perspective of socio-economic changes of a country, the pattern of its changes in Bangladesh is to meet the dynamic demand of the society that creates pressure on natural environment. As a result, various disharmonies occur in natural system. In fact, the land use change is the changes of men's activities on land which mostly occur in two ways: firstly, changes from one type to another and secondly, changes into a type i.e. either decreasing or increasing. Both types of changes take place in Bangladesh. Among the changing pattern the changes of agricultural land is remarkable in a land hungry country like Bangladesh. The total arable land of the country is not more than 0.782 crores ha and per capita land is only 0.0526 ha. Moreover, every year $1 \%$ of its arable land or 82900 ha of crop land and everyday 221 ha of arable land is losing in Bangladesh. Despite the remarkable achievement in controlling the high birth rate, the population continues to grow by 2 million people each year because of the large existing population base (Mahabub 2003). The country's population will be over around 190 million by 2030 when an extra $25 \%$ food grains will have to be produced. But the additional harvests will have to be reaped from a much smaller area of cropland than is now available (Bhuiyan 2003). According to one projection, the country would have to grow an additional five to six millions tones of grains by 2020 in a land area two million ha less than today. In this perspective land use changing pattern is a challenge for agricultural land.

The term land use has been defined differently from various perspectives by different scholars. It has seen as 
a product of interactions between a society's cultural background, skill and its physical needs in one hand, and the natural potential of land on the other (Ram and Kolakar 1993). Land use is also defined as men's activities on land, which are directly related to land. Vink (1975) pointed out that the later is a subset of the former stating. Land use is characterized by the arrangements, activities and inputs by people to produce change or maintain a certain land cover type (Di Gregorio and Jansen 1998). Land use defined in this way therefore establishes a direct link between the land cover and the actions of people in their environment (Lillesand and Kiefer 2002). Land cover is the observed biophysical cover on the earth's surface. In other words, land use $=$ land cover + land utilization (Di Gregorio and Jansen 1998). Further, land use is the arrangements, activities and inputs that people undertake on a certain land cover type (FAO 2000). According to these definitions land use reflects human activities such as the use of the land like industrial zones, residential zones, agricultural fields and so on. The above definitions establish a direct link between land and the actions of people in this environment.

For studying land use changes pattern, remotely sensed data such as aerial photograph and satellite imageries are undoubtedly the most dependable for extracting information (Rahman et al. 2005). In this study, remotely sensed data have been used for identifying land use pattern. To find out the rate of land use changes, change detection is a suitable technique (Singh 1989). Change detection is a technique that is used to highlight conversion of land from one use to another within a given time frame (Jaysal and Ram 1999). In this study an attempt has been made to detect the land use changes through an integrated satellite image and geographical information system techniques (Rahman and Saha 2009). The objectives of the present research were: (a) to examine the land use pattern in the study area, (b) to detect the land use change pattern; and (c) to find out the challenges for agricultural land.

\section{Materials and Methods}

Spatial extent: The spatial extent of this study is between $24^{\circ} 12^{\prime}$ to $24^{\circ} 42^{\prime} \mathrm{N}$ latitude and $88^{\circ} 15^{\prime}$ to $88^{\circ} 50^{\prime} \mathrm{E}$ longitude, which belongs to Rajshahi District of Bangladesh. It covers an area of $2407 \mathrm{sq} . \mathrm{km}$, is bounded by Naogaon District to the North, Natore District to the East, Chapai Nawabgong District to the west and the river Padma to the South (Fig. 1). It consists of 9 Upazilas, 4
Thanas, 13 Municipalities, 147 Wards, 297 Mahallas, 70 Union Parishads, 1678 Mouzas and 1858 villages. Under Koppen climatic classification Rajshahi District has a tropical wet and dry climate. The average temperature is $22-25^{\circ} \mathrm{C}$ and rainfall is about $1448 \mathrm{~mm}$. Total land of the study area is 5994405 ha, where agriculture, infrastructures and others constitute 394986.32 ha, 117615.42 ha and 63829.56 ha, respectively. Total population of the study area is 2833256 and population density is 1177 per sq. km (BBS 2008).

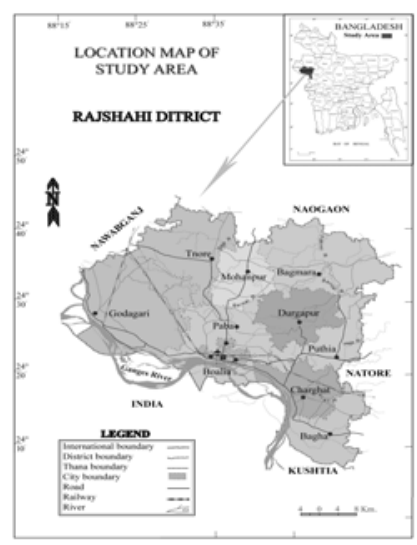

Fig. 1. Location map of the study area.

Collection of experimental data: The key data for this study were collected by remote sensing techniques (Yang and Lo 2000). The FCC colour hard copies of Landsat MSS-1977, Landsat TM-1990, and Landsat TM-2010 (Rahman et al. 2005; Rahman and Saha 2009) have been used (Table 1). In addition, a large number of published and unpublished text materials related to the present topic also have been used. Among these BBS (1978; 2002; 2005) and Banglapedia (2006) are especially mentionable.

For identifying the land use pattern and change detection Landsat data and their objects were identified with tonal variation and GPS survey. The land use patterns, their classifications (Anderson 1970) and land use maps of study area of three different time periods were prepared with Arc. GIS Software (9.2). Land use or land cover classification prepared by Anderson et al. (1976) is a better known classification which is also known as USGS (United States Geological Survey) land classification system. This classification system has been followed here.

Table 1. Remote sensing data used in the present study.

\begin{tabular}{|l|l|l|l|l|l|}
\hline Platform & Product & Bands & Resolution & Time/ Session & Format \\
\hline Landsat-TM & Colour digital FCC copy & $\mathrm{R}(4) \mathrm{G}(3) \mathrm{B}(2)$ & 30 metres & 21 January 2010 & Hard copy \\
\hline Landsat-TM & Colour digital FCC copy & $\mathrm{R}(4) \mathrm{G}(3) \mathrm{B}(2)$ & 30 metres & 30 January 1990 & Hard copy \\
\hline Landsat-MSS & Colour digital FCC copy & $\mathrm{R}(7) \mathrm{G}(5) \mathrm{B}(4)$ & 30 metres & 10 February 1977 & Hard copy \\
\hline
\end{tabular}


Moreover, the area of different classes of land use maps was measured and their changes were detected with map

and statistical applications. The methodology has been detailed in Fig. 2.

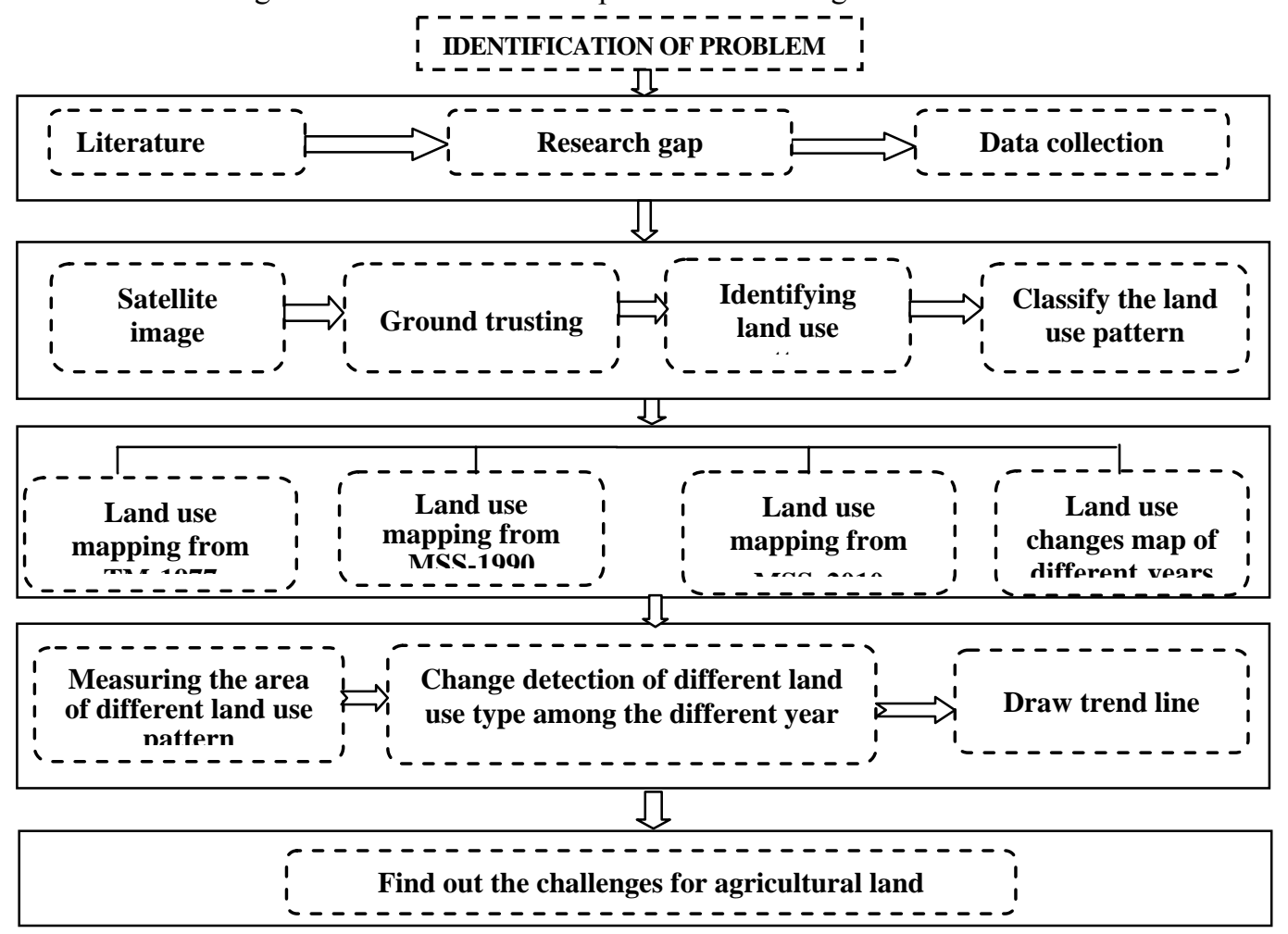

Fig. 2. Diagram showing the methodology for this study.

\section{Results and Discussion}

Land use pattern of the study area: The major land use pattern of Rajshahi District has been categorized into the following classes: agricultural land, infrastructural land, orchard, water bodies, fallow land, char land, char agricultural land, and river area. Total land area of Rajshahi District is 577472.28 acres. Of this, agricultural land is 394486.32 acres, infrastructural land 117115.42 acres, orchard 11113.9 acres, fallow land 11070.78 acres, water bodies 19817.49 acres, char land 13281.8 acres, and river area 7547.65 acres. The land use pattern of the study area in 1977, 1990 and 2010 is shown in Figs. 3 and 4.

Changes in land use pattern in the study area: Land use pattern changes in three different time periods have been examined for detecting the land use changes in Rajshahi District. It is clear from the results that the agricultural land, fallow land, river area, and water bodies have decreased, whereas the infrastructural area and char land have increased proportionately (Table 2). The agricultural land of Rajshahi District in 1977 was 186056.74 ha (i.e. $75.58 \%$ of the total land area) and in 2010 it became 159913.48 ha $(68.31 \%)$. It has therefore been decreased to $14.02 \%$ during the last 33 years, indicating $0.46 \%$ decline per year. The infrastructural land was 16161.38 ha $(6.91 \%)$ in 1977 and 47617.58 ha $(20.28 \%)$ in 2010 , suggesting that it has increased $194.63 \%$ during the period; which is $5.90 \%$ decline per year. Like wise, the area under orchard was 3781.95 ha $(1.62 \%)$ in 1977 and 4499.55 ha $(1.93 \%)$ in 2010 . The fallow land was 8666.05 ha $(4.38 \%)$ in 1977 and 4482.09 ha $(1.92 \%)$ in 2010 . The area under water bodies was 10235.95 ha $(4.38 \%)$ in 1977 and 8428.13 ha $(3.44 \%)$ in 2010 , suggests that they have been diminished $17.66 \%$ during the period. The river area was 6425.07 ha $(2.75 \%)$ in 1977 and 3055.72 ha $(1.31 \%)$ in 2010. So, the river area has been declined $52.44 \%$ during the past 33 years, indicating a $1.60 \%$ decline per year. Conversely, the char land has been amplified because its area was 2071.20 ha $(0.89 \%)$ in 1977 and 5377.25 ha $(2.3 \%)$ in 2010 .

Challenges for agricultural land: The land use changing pattern of Rajshahi District described above revealed that the agricultural land is facing a greater challenge. Although the rate of decline is smaller than other types of changes, its vast amount is concerning more than other changes. The agricultural land of the study area has been decreased $14.05 \%$ during the past 33 years and at a rate of $0.46 \%$ per year which is shown in Table 3 . 


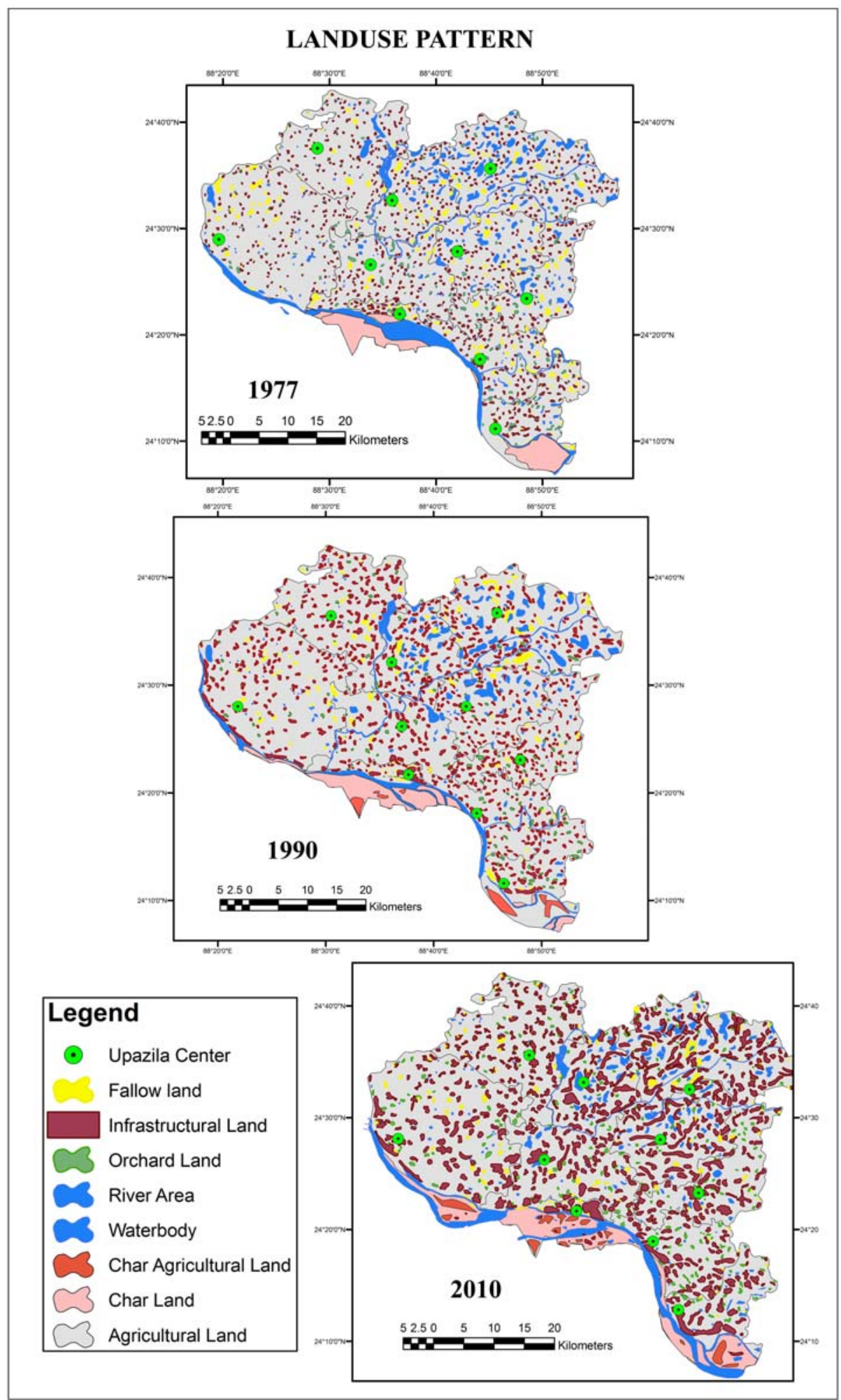

Fig. 3. Land use pattern of Rajshahi District in 1977, 1990 and 2010 (Source: Landsat MSS-1977, Landsat TM-1990 and Landsat TM-2010). 
Although the areas under agricultural land, water bodies, fallow land and rivers have been lessening, the infrastructural land and char land have been increasing steadily over the same period. This trend suggests that the agricultural land is converting into other type of land use, especially applicable for the infrastructural land (Islam 2000). The orchard area has been reduced during 1977-1990 but increased during 1990-2010. That means some new area (especially agricultural land) has been converted into orchards such as mangoes, litchi and plum $(K u l)$ in the study area. In other words, it speaks that every year agricultural land is decreasing by the increasing areas of the infrastructure and orchards. These findings corroborate to those reported earlier (Islam 2000; Rahman et al. 2005; Rahman and Saha 2009).

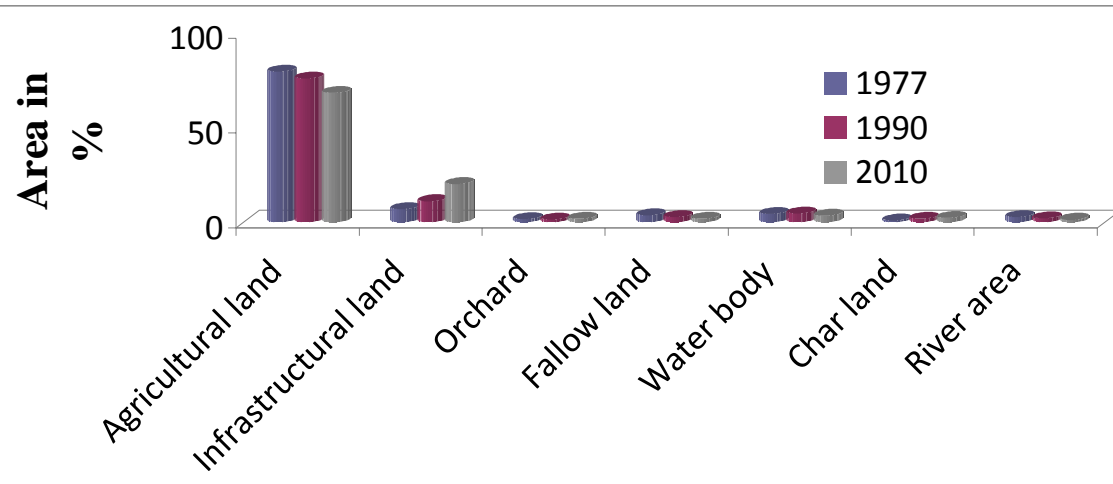

Land use pattern

Fig. 4. The classified land use pattern of Rajshahi District in 1977, 1990 and 2010 (Source: Landsat MSS-1977, Landsat TM-1990 and Landsat TM-2010).

Table 2. Land use changes of Rajshahi District during 1977-2010.

\begin{tabular}{|c|c|c|c|c|c|c|c|c|c|}
\hline 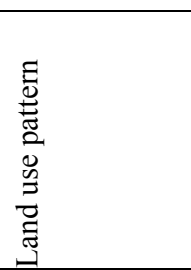 & 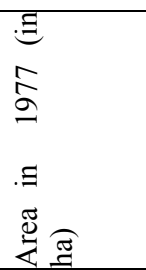 & 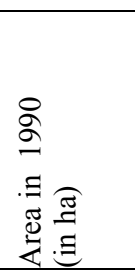 & 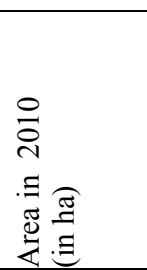 & 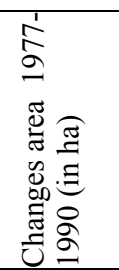 & 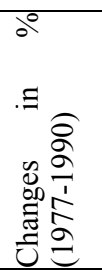 & 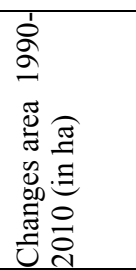 & 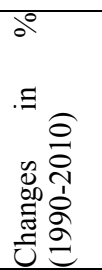 & 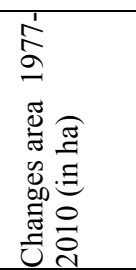 & 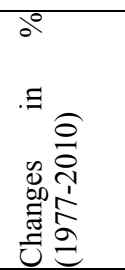 \\
\hline Agricultural & 186056.74 & 177564.6 & 159913.48 & 8492.10 & -4.65 & 17853.58 & -9.95 & 26143.25 & -14.05 \\
\hline Infrastructural & 16161.36 & 26017.23 & 47617.58 & 9859.98 & +60.98 & 21600.34 & +83.02 & 31456.27 & +194.63 \\
\hline Orchard & 3781.95 & 3438.43 & 4499.55 & 343.34 & -9.08 & 1061.13 & +30.86 & 717.76 & +18.97 \\
\hline Fallow land & 8666.05 & 6613.66 & 4482.09 & 2052.40 & -23.68 & 2131.58 & -32.22 & 4183.98 & -48.27 \\
\hline Water bodies & 10235.95 & 10410.94 & 8428.13 & 134.61 & -1.32 & 1982.81 & -19.05 & 1807.81 & -17.66 \\
\hline Char land & 2071.20 & 4393.17 & 5377.25 & 2321.97 & +112.1 & 984.07 & +22.40 & 2901.19 & +140.79 \\
\hline River area & 6425.07 & 4951.13 & 3055.72 & 1392.97 & -22.94 & 3369.34 & -52.44 & 3369.34 & -52.44 \\
\hline
\end{tabular}

Source: Landsat MSS-1977, TM-1990 and TM-2010 image analysis.

Table 3. Losses of agricultural land of Rajshahi District during 1977-2010.

\begin{tabular}{|l|l|l|l|l|}
\hline Year & $\begin{array}{l}\text { Agricultural } \\
\text { land (ha) }\end{array}$ & Duration & $\begin{array}{l}\% \\
\text { Decreased }\end{array}$ & $\begin{array}{l}\% \\
\text { Change } \\
\text { s per } \\
\text { year }\end{array}$ \\
\hline 1977 & 186056.74 & - & - & - \\
\hline 1990 & 177564.61 & $1977-1990$ & 4.57 & -0.36 \\
\hline 2010 & 159913.49 & $1990-2010$ & 11.03 & -0.55 \\
\hline & & $1977-2010$ & 14.05 & -0.46 \\
\hline
\end{tabular}

Source: Satellite Images of Landsat 1977-MSS, 1990-TM and 2010-TM analysis.
Forecast on the changing pattern: For forecasting on the land use changing pattern of the study area, the following hypotheses have been considered: (i) the agricultural land losing rate will be constant; (ii) the infrastructural development rate will also be constant; and (iii) there would be no action taken to protect the arable land. If so, the agricultural land would be eliminated completely within the next 217 years (Fig. 5). That means the agricultural land of Rajshahi District will totally be dropped out within 2228 AD. From the above forecasting it is clear that the agricultural land of Rajshahi is facing a great challenge. 


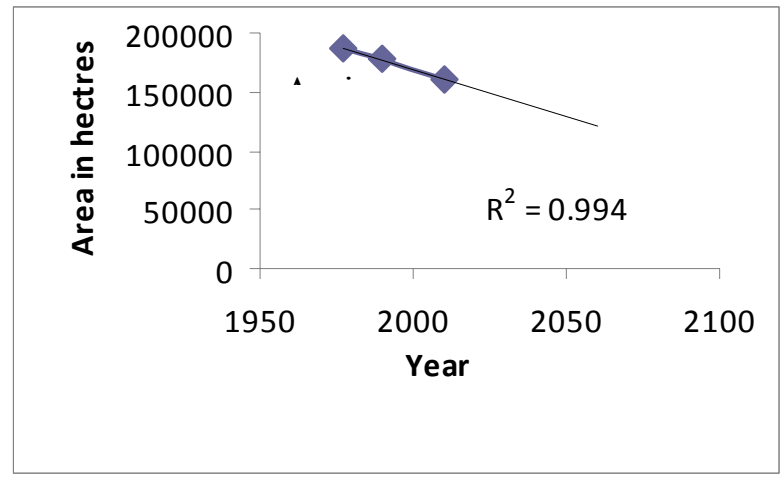

Fig.5. Forecasting on agricultural land losses in Rajshahi District (Source: Satellite Images of 1977-MSS, 1990TM, 2010-TM analysis).

Recommendations: The land use pattern of Rajshahi District has been changing rapidly which is creating pressure on agricultural land. Without taking proper planning and implementation of the agricultural land of the study area, this trend would face a great challenge. Based on the present findings, the following recommendations are proposed for future planning: (a) the infrastructure should be developed vertically; (b) zonal growth planning should be accumulated; (c) taxes can be imposed for new infrastructures; (d) population growth rate should be controlled; and most importantly (e) awareness should be grown up among the people.

\section{Conclusion}

With uncontrolled population growth and economic development in the study area, the land use pattern is changing rapidly. This is especially true for infrastructural lands, which have increasingly expanded and encroached upon agricultural land during the last few years. Using remote sensing data integrated with GIS, it was found that agricultural land of the study area is losing by $0.46 \%$ per year. If this rate continues, no agriculture land would be available within the next 217 years. To face the challenges, a few recommendations such as vertical development of infrastructures and imposing of taxes on such structures, accumulated zonal growth planning, population growth control and development of awareness among the people have been proposed.

\section{References}

Anderson JR. 1970. A Geography of Agriculture. WMC Brown Co., Dubuque, Iowa, USA.

Anderson JR, Hardy EE, Rooch JT and Witmer RE. 1976. Land Use and Land Cover Classification System for Use with Remote Sensor Data (Professional Paper 964), Reston, VA: USGS.
Banglapedia 2006. National Encyclopedia of Bangladesh. Asiatic Society of Bangladesh. Genesis Printing and Packaging, Dhaka.

BBS (Bangladesh Bureau of Statistics) 1978. Statistical Yearbook of Bangladesh. Ministry of Planning, Dhaka. Govt. of Bangladesh.

BBS (Bangladesh Bureau of Statistics) 2002. Bangladesh Population Census, 2001. Ministry of Planning, Dhaka. Govt. of Bangladesh.

BBS (Bangladesh Bureau of Statistics) 2005. Census of Agriculture, 2000. Zilla Series, Rajshahi. Bangladesh Bureau of Statistics, Dhaka, Bangladesh.

BBS (Bangladesh Bureau of Statistics) 2008. Economic Review 2008. Ministry of Planning. Government of Bangladesh.

Bhuiyan M. 2003. Has urbanization caused agricultural land loss? The Daily Star, November 12003.

Di Gregorio CM and Jansen J. 1998. A new concept for a land cover classification system. Land 2(1): 55-58.

FAO (Food and Agriculture Organization) 2000. Yearbook 49: Production. Rome, Italy.

Islam KN. 2000. Temporal Mapping and Spatial Analysis of Land Transformation Due to Urbanization and its Import on Surface Water System: A Case from Dhaka Metropolitan Area. Int. Arch. Photogram. Remote Sensing XXX(B7): Amsterdam.

Jaysal RK and Ram R. 1999. Application of remote sensing technology for land use/land cover change analysis. $J$. Indian Soc. Remote Sensing 27(2):

Lillesand TM and Kiefer RW. 2002. Remote Sensing and Image Interpretation. John Wiley and Sons, Inc. New York.

Mahbub A. 2003. Agricultural land loss and food security: An assessment. IRRI, Manila, The Philippines.

Rahman MR and Saha SK. 2009. Spatial dynamics of cropland and cropping pattern changes analysis using landsat TM and IRS P6 ISSII satellite images with GIS. GeoSpatial Info. Sci. 12: 17-21.

Rahman MR, Islam AHM and Hassan MS. 2005. Change detection of winter crop coverage and the use of Landsat data with GIS. J. Geo- Environ. 4: 1-13.

Ram R and Kolakar S. 1993. The Future of Our Land: Facing the Challenge. Hall of India Pvt. Ltd., New Delhi.

Singh A. 1989. Digital change detection techniques using remotely sensed data. Int. J. Remote Sensing 10: 9891003.

Vink RK. 1975. A framework for land evolution. www.mpl.fr/creat/tallercolumbia/FAO/AGLL/pdf.docs

Yang X and Lo CP. 2000. Relative radiometric normalization performance for change detection from multi date satellite images. Photogram. Eng. Remote Sensing 66: 967-980.

Manuscript received on 10 October 2011 and revised on 24 December 2011 